\title{
LAND CONSOLIDATION IN POLAND AS A TOOL FOR THE IMPROVEMENT OF FARMING CONDITIONS IN TERMS OF RURAL DEVELOPMENT- CASE STUDY
}

\author{
Katarzyna Sobolewska-Mikulska ${ }^{1}$, Prof. \\ 1, Warsaw University of Technology, Faculty of Geodesy and Cartography
}

\begin{abstract}
Improvement of farming conditions and increased profitability of farms in Poland are closely related to implementation of land consolidation works, which are performed insufficiently comparing to the demands. The paper aims to analyse the improvement of farming conditions resulting from land consolidation based on the selected research site - land consolidation object "Adrianki". The study concerned economic, environmental-and-landscape and legal-and-social aspects of the land consolidation effects. Results of the research proved that the farming conditions in the analysed agricultural holdings were improved based on the values of shape expanse coefficient; it decreased comparing to its values before land consolidation. Environmental-and-landscape results remained neutral what means that environmental conditions were not improved, but, on the other hand, they were not worsened. However, satisfactory legal-and-social effects were obtained since the legal status of all real estates was settled and updated cadastral data was obtained. What refers to social effects, there can be indicated increased interest in land consolidation works within the areas neighbouring to the research site. The analysed results of land consolidation works stay in accordance with the Rural Development Programme and they allow to consider rural areas as places of work, living, rest and recreation.
\end{abstract}

Key words: land consolidation, farming conditions, development of rural areas.

JEL code: Q15

\section{Introduction}

Within the Common Agricultural Policy (CAP) of the European Union, the Rural Development Programme (RDP) is performed. It is aimed at limitation of conventional forms of farming within rural areas (in particular, the agricultural production) and introduction of new functions of rural areas. The Rural Development Programme includes sustainable and multifunctional development of areas, where relations between the agriculture, the village and the natural environment remain in balance. This programme was also initiated in Poland. According to the provisions of the Agenda 2000, the agriculture - apart from conventional production functions - may play an important role in the area of the environment protection, among others, in the field of protection of soils, landscape and biodiversity of natural habitats. In the case of agriculture in Poland, it is extremely important to promote the idea of the multifunctional rural development, in particular, with respect to activities aiming at diversification of the agricultural production and improvement of the profitability of farming. In the long-term perspective, the multifunctional development of rural areas should be performed with consideration for economic, social and environmental aspects. The idea of the multifunctional development of rural areas in Poland should be implemented through inter alia:

- improvement of effectiveness and profitability of farms,

- maintaining environmental-and-landscape structures,

- improvement of conditions of the technical infrastructure in the Polish villages.

Taking into account the current conditions of farming in Poland, it is impossible to reach the balance in the above areas without implementation of land consolidation works. Literature and statistical data review proves that the high regional diversification of the area structure of parcels and farms still exists in Poland (Woch, 2006; Sobolewska-Mikulska, 2009). Therefore, improvement of spatial structure of farms performed in parallel with decreasing the number of farms and increasing their size is the required and priority task. The system of co-financing of 
activities performed in rural areas in Poland is also supported by the European structural funds. The first tranches of payments took place in the period 2007-2013 and they equalled to approximately 28.6 billion euros. Next subsidies, aiming at restructuring, modernisation and development in parallel with environmental protection and the agricultural landscape arrangement activities are currently being spent (2014- 2020); they equal to 32.1 billion euros (data from the Ministry of Agriculture and Rural Development, 2016). Beneficiaries of the discussed financial means are farmers who should modify their activities towards diversification of incomes and the multifunctional development (Roszkowska-Madra, 2009). The current agricultural policy assumes the increased profitability of farms and competitiveness of all forms of activities, promotion of innovative technologies in agricultural households through structural changes and wide implementation of surveying works - land consolidation operations.

Land consolidation is the conventional legal-and-technical solution which creates the possibility to improve conditions in the agriculture and forestry. As it was proved by performed analyses, high demands for such works exist in Poland. The land use structure in Poland is one of the worst in Europe. The analysis of data of the Agency for Restructuring and Modernisation of Agriculture (ARMA) of 2014 proves that urgent land consolidation works are required for about 7.1 million hectares, i.e. approximately $70 \%$ of all arable lands in Poland. At present, land consolidation works in Poland are performed according to the act on land consolidation and exchange (Ustawa..., 1982). Land consolidation works include inter alia:

- delineation of new cadastral parcels of improved parameters (e.g. shape),

- reduction of small parcels,

- improvement of land tenure structure,

- improvement of shape expanse of lands in the agricultural holdings,

- implementation of post-consolidation investments (e.g. construction of new road infrastructure). When referring to the multifunctional development, land consolidation effects may be divided into three main groups, including:

1) economic effects;

2) environmental-and-landscape effects;

3) legal-and-social effects.

Re: 1. Economic results directly illustrate the objectives of land consolidation works defined in the Act (Ustawa..., 1982). They directly refer to creation of more advantageous conditions in farming and forestry. Both, external and internal factors influence the correct use of lands for the agricultural production. Land consolidation allows to interfere with external factors and, at the same time, to support the increase of the effectiveness of the agricultural production. It is possible to reach such affects, among others, as a result of reduction of the number of parcels in a farm and the rational configuration of parcels in relation to a settlement area. Increased sizes of arable parcels are the additional effect. Besides, the rational configuration of parcels in a farm results in shortening of the transportation time and the distances between the settlement and the fields. Another important land consolidation effect is the correction of shapes of parcels, including the adaptation of their borders to the terrain relief, as well as to the transportation and hydrological networks and water melioration (reclamation) installations which divide arable lands into hardly accessible pieces. As a result, the number of small, ineffective parcels of irregular shapes is minimised. The design of functional agricultural road system is another crucial effect. Functional transportation routes ensure the possibility to apply more effective methods and machinery for the 
agricultural production. Newly designed cadastral parcels have facilitated access to public roads as a result of construction of culverts and turnoffs. Another land consolidation effect concerns recultivation of areas useless for the agricultural production and elimination of unnecessary roads and balks.

Implementation of the mentioned design solutions resulting in economic effects, aims at reduction of costs of the agricultural production and increase of profitability of farms.

Re: 2. Environmental-and-landscape results of land consolidation may be divided into effects related to protection of lands, vegetation and animals, and effects related to creation of landscape and improvement of environmental aspects. The first group of effects includes, first of all, actions against water and wind erosion and regulation of groundwater level in arable lands. Mentioned tasks may be performed by combination of both functions through arrangements of the rational agricultural-and-forest border. This allows for adaptation of land use to soil conditions and to selected directions of the agricultural production. Another important effect of land consolidation is the increase of forest cover in Poland. Introduction of afforestation considerably diversifies the agricultural landscape and results in the increased attractiveness of villages as places for recreation and rest; this, in turn, influences diversification of incomes and development of non-agricultural activities. Agro-tourism is often connected with ecological farming; interest in this type of farming has been constantly growing among rural and urban population.

Re: 3. According to the provisions of Act (Ustawa..., 1982) legal-and social effects of land consolidation works lead to updating and setting the legal status of real estates by achieving the consistency between property registers and data included in the real estate cadastre. The result is the updated legal documentation and the creation of cadastral databases according to currently required parameters. Parcel borders are permanently fixed in the field, according to provisions included in the documentation. The land consolidation process also allows to designate and secure land for construction of technical and social infrastructure.

The above possible effects contribute to the increase of economic activeness of farms what, in turn, influences the growth of social satisfaction from the transformation processes. It is a highly positive phenomenon.

Rural areas, defined in the European Charter for Rural Areas (1996) are inland or coastal countryside, including small towns and villages, where the main part of the area is used for agriculture, forestry, aquaculture and fisheries, economic and cultural activities of countrydwellers, non-urban recreation and leisure areas [or natural reserves], and other purposes, such as housing. Rural areas in Poland are highly diversified; when analysing the agrarian structure and economic conditions of individual farms are analysed, three megaregions of rural areas in Poland may be distinguished (Fig. 1). 


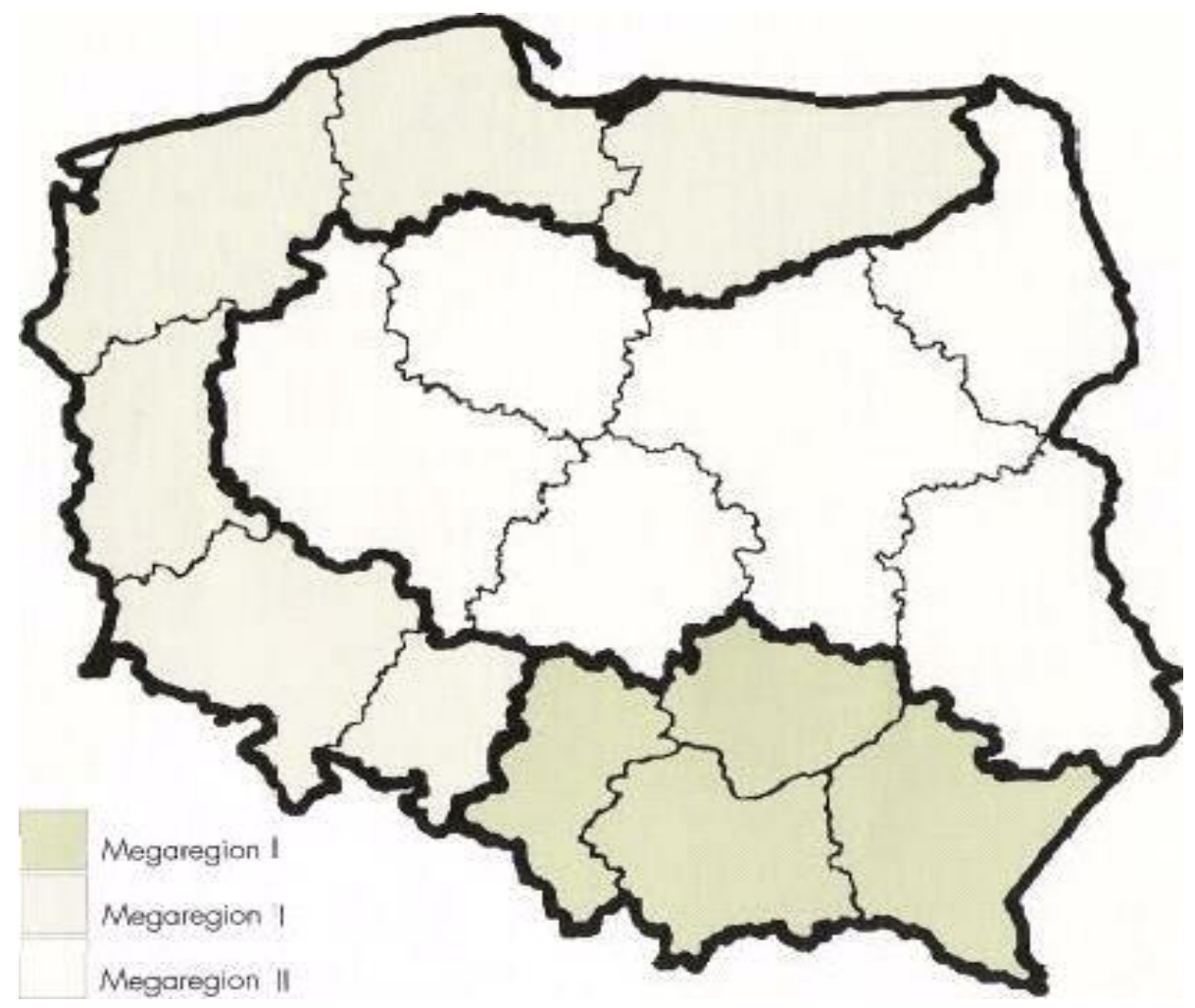

Source: The coherent structural policy of development of rural areas and the agriculture. The document approved by the Council of Ministers in 1999, Warszawa $1999 r$.

Fig. 1. Boundaries of mega-regions of the agriculture and rural areas in Poland

The megaregion I is characterised by the highest fragmentation of farms. The average size of a farm in the megaregion I equals to 2.5-4.0 ha.

Large farms are dominating in the megaregion $\mathrm{II}_{\text {, }}$ which require fast arrangements of spatial structures remaining after the State Farms. This is a poor region characterized by high unemployment and low social activeness.

The megaregion III is relatively best balanced with respect to economic, ecological, demographic and social aspects. Two thirds of Polish farms are located within this megaregion; they are considered as farms which may be activated and multifunctionally developed when they gain financial support.

Since the accession of Poland to the European Union in the year 2004, positive changes in the structure of the Polish agriculture may be noticed. This concerns, first of all, the issue of concentration of farms. In order to adapt to the European Union standards, many farms have undergone the process of specialisation and modernisation. However, in Poland, many smallest and economically weakest farms terminated their agricultural production. Basing on the results of the National Agricultural Census 2010 (Powszechny..., 2010), the total number of farms had decreased by more than $22 \%$ (from 2.9 million to 2.3 million) in the period 2002-2010; this reduction concerned $33.8 \%$ farms with $1-2$ ha of arable lands. Despite this, farms of the size between 1-5 ha of arable lands were still the highest percentage in the structure of farms - $37.8 \%$. Considerable increase in the number of farms could be noticed in size group above 30 ha of arable lands; in the case of farms between 30 and 50 hectares the percentage was equal to $12.5 \%$ and the number of farms with more than 50 ha of arable lands increased by more than $40 \%$ in the analysed period. Comparing to the results of the National Agricultural Census 2010 data acquired 
in 2013 (GUS 2014), it is possible to indicate the continuous trend of the reduction in the number of farms and the increase of their average total size (from 11.26 ha to 11.54 ha and from 9.85 ha to 10.22 ha, respectively). Despite this, the average size of arable lands in one farm still remains much smaller comparing to countries of the similar assortment of production, which are the competitors for the Polish agriculture, such as the Czech Republic (152.4 ha), Germany (55.8 ha), France (53.9 ha) (Poczta, 2013).

Presented information allows to formulate the thesis that structural transformations of Polish agriculture are required and land consolidation works should be intensified.

\section{Research object and methods}

The paper aims to analyze the improvement of farming conditions resulting from land consolidation based on the scope of design solution implemented in the land consolidation project for the selected research site - land consolidation object "Adrianki". In order to reach the aim, the author set the following research tasks according to the scope of analysis:

1) The assessment of farming conditions, including:

- analysis of fragmentation of land in individual farms,

- analysis of shapes of agricultural parcels in farms,

- analysis of shape expanse (configuration of lands) in farms,

- analysis of changes in the agricultural roads system,

- analysis of changes in the water melioration (reclamation) system.

2) The assessment of the impact of land consolidation on the landscape and the environment

3) The assessment of legal-and-social effects of land consolidation.

The research was based on the surveying documentation, including cadastre databases and cadastral maps presenting the state before and after land consolidation, as well as land consolidation documentation. The investigation of changes in the farming conditions included analysis of geometrical data of agricultural plots and their number and the analysis of the values of Moszczenski coefficient representing the shape expanse of lands in farms. The analysis of the road system was based on the analysis of cadastral maps and cadastral database. Studies on the impact of land consolidation on the landscape and the environment were carried out on the basis of an environmental study documentation and the Environmental Impact Assessment report. The investigation of legal effects of land consolidation was carried out on the basis of cadastral data, whereas the social effects were defined based on the interviews with farmers' representatives.

Comparative and analytical methods in the case study approach were applied as research methods. The research object - Adrianki village (1.484 hectares) is located in the Podlaskie Region (Fig. 2). The Lesna River flows through the village. The village is also crossed by the national road. Frequent melioration ditches, as well as historical and cultural places are characteristic features of this village (such as the Orthodox Church and the manor complex of the $19^{\text {th }}$ century). 


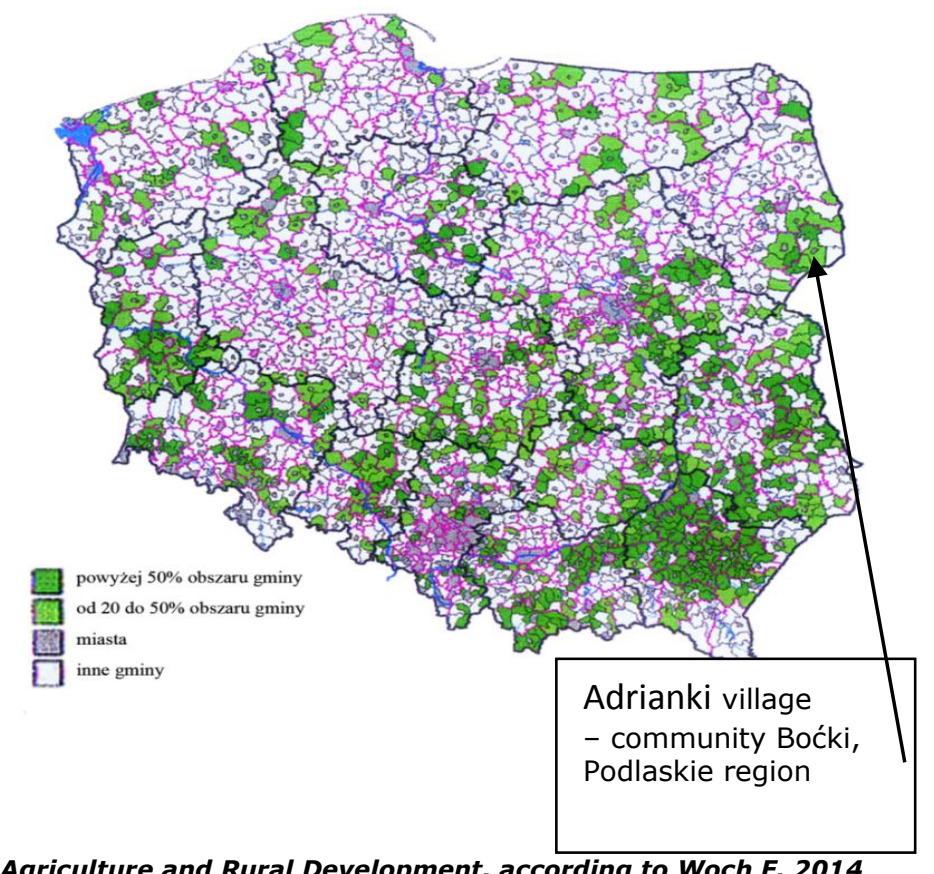

Source: The Ministry of Agriculture and Rural Development, according to Woch F. 2014

Fig. 2. The indicative location of research site on the map of the assessment of demands for land consolidation works by Polish municipalities, with specification of approximate locations of analysed areas

\section{Research results and discussion}

The objective of land consolidation works of the Adrianki site was to create more advantageous conditions of farming and forestry. The initial lack of farmers' interests in the discussed activities was gradually changing into the growing involvement of the local society; it was the result of the growing involvement of the project team in discussions and presentations of possible project results. The presentation of expectations of land consolidation participants concerning changes and, in particular, corrections (such as straightening parcel lines) and changes of locations of fields was the result of land consolidation promotion activities. Other effects which improved farming conditions are presented below.

\section{Economic effects}

5 farms were analysed; the size of each farms exceeded 15 ha and the number of parcels in each farm exceeded 10. The total areas of analysed farms equalled to $116.88 \mathrm{ha}$, with 104 parcels of the average size of 1.26 ha. After the land consolidation works the size of farms was increased to 139.56 ha, the number of parcels was reduced by 33 , and the average parcel size equalled to $1.82 \mathrm{ha}$. What is also important, sizes of all, newly designed farms were increased to more than 20 ha after the land consolidation works.

- The analysis of fragmentation of lands in individual farms

The land consolidation area equals to 1484.57 ha. Before land consolidation it included 1204 cadastral parcels. Individual farms covered the area of 1330.15 ha and 1107 parcels. The average parcel size before land consolidation in an individual farm equalled to 1.20 ha. After land consolidation the area of farms was changed and it equals to 1484.34 ha. The average parcel size was increased to $1.58 \mathrm{ha}$.

- The analysis of shapes of parcels in farms 
The investigation of shapes of parcels was performed based on the analyses of proportions between the parcel lengths and widths. For geometrically irregular parcels such analyses were not performed. The analysed parcels were divided with respect to:
- the parcel width smaller than $10 \mathrm{~m}$,
o the parcel width smaller than $20 \mathrm{~m}$,
- proportion of parcel sides smaller or equal to $5: 1$,
- proportions of parcel sides greater than $5: 1$, but smaller or equal to $10: 1$,
- proportions of parcel sides greater than 10:1, but smaller or equal top 20:1,
- proportions of parcel sides greater than 20:1.

The results of performed analyses are presented in Table 1.

Table 1

The analysis of shapes of agricultural parcels in farms, the Adrianki site

\begin{tabular}{|c|c|c|c|c|c|c|c|}
\hline & \multirow{2}{*}{$\begin{array}{l}\text { The total } \\
\text { number of } \\
\text { analysed } \\
\text { parcels }\end{array}$} & \multicolumn{2}{|c|}{$\begin{array}{l}\text { The number of } \\
\text { parcels of the width }\end{array}$} & \multicolumn{4}{|c|}{$\begin{array}{l}\text { The number of parcels with proportions } \\
\text { of sides }\end{array}$} \\
\hline & & $\begin{array}{l}\text { Less } \\
\text { than } \\
10 \mathrm{~m}\end{array}$ & $\begin{array}{l}\text { Between } \\
10.0 \text { and } \\
20.0 \mathrm{~m}\end{array}$ & $\leq 5: 1$ & $5: 1 \div 10: 1$ & $10: 1 \div 20: 1$ & $>20: 1$ \\
\hline $\begin{array}{l}\text { Data prior to land } \\
\text { consolidation } \\
\text { works }\end{array}$ & 27 & 174 & 289 & 261 & 214 & 223 & 382 \\
\hline $\begin{array}{l}\text { After land } \\
\text { consolidation } \\
\text { works }\end{array}$ & 13 & 32 & 132 & 283 & 211 & 194 & 152 \\
\hline Difference & 14 & 142 & 157 & -22 & 3 & 29 & 230 \\
\hline
\end{tabular}

Source: author's work based on the cadastral data for the Adrianki site

Tests concerning the shapes of parcels proved that the increased parcel width does not always result in the improved proportion of the parcel sides.

- Analysis of configuration of lands in farms

In order to determine the configuration of lands in farms, the Moszczenski (1927) formula was applied:

$$
\mu=\frac{K \times L}{1.53 \times P}
$$

$\mu$ - shape expanse (land configuration) coefficient of a farm;

$K$ - the length of parcel circumference $[\mathrm{m}]$;

$L$ - the distance between parcels and the farm centre $[\mathrm{m}]$;

$P$ - the farm size $[$ ha];

1.53 - the correcting coefficient.

Table 2 presents calculations of the shape expanse coefficient for 5 selected farms. 


\section{Shape expanse coefficients before $\left({ }^{\mu 1}\right)$ and after $\left({ }^{\mu 2}\right)$ land consolidation for the analysed farms in the Adrianki site.}

\begin{tabular}{|c|c|c|c|c|c|c|c|c|c|}
\hline \multirow{2}{*}{$\begin{array}{c}\text { Number } \\
\text { of farms }\end{array}$} & \multicolumn{6}{|c|}{ Prior to land consolidation (1) } & \multicolumn{2}{|c|}{ After land consolidation (2) } & Difference \\
\cline { 2 - 9 } & $\boldsymbol{P}_{\mathbf{1}}$ & $K_{\mathbf{1}}$ & $L_{\mathbf{1}}$ & $\mu 1$ & $\boldsymbol{P}_{\mathbf{2}}$ & $K_{\mathbf{2}}$ & $L_{\mathbf{2}}$ & $\mu 2$ & $\mu 1-\mu 2$ \\
\hline $\mathbf{1}$ & 16.82 & 944.5 & 13.50 & 495.0 & 24.29 & 903.4 & 1334.6 & 323.0 & -172.0 \\
\hline $\mathbf{2}$ & 20.42 & 885.8 & 2558.3 & 725.0 & 25.14 & 893.1 & 2158.3 & 501.0 & -224.0 \\
\hline $\mathbf{3}$ & 23.08 & 866.0 & 2990.0 & 733.0 & 26.04 & 785.3 & 2453.6 & 484.0 & -249.0 \\
\hline $\mathbf{4}$ & 25.81 & 955.8 & 2568.7 & 622.0 & 27.64 & 949.4 & 1833.3 & 412.0 & -210.0 \\
\hline $\mathbf{5}$ & 30.75 & 816.6 & 1515.8 & 263.0 & 36.45 & 835.1 & 1460.6 & 219.0 & -44.0 \\
\hline
\end{tabular}

Source: author's work based on the cadastre database for the Adrianki site

The analysed shape expanse coefficient for selected farms decreased by - 179.0 as an average; it is not the best result. However, the analysis of land consolidation documentation proved that it corresponded to social expectations for the project.

- The analysis of changes in the agricultural road system

Before land consolidation the road system included 47 municipal roads of the total length of $3.49 \mathrm{~km}$. The average width of a pavement equalled to $6.5 \mathrm{~m}$, and the area covered by all roads in the village was equal to 25.21 ha. High difficulties for farming which resulted in increased costs and longer access times were caused by the high number of parcels belonging to individual farms without the access to public roads. After land consolidation works all parcels have access to roads, which were widened to $12 \mathrm{~m}$; this allowed for two-way traffic of agricultural machinery. In places where such solutions were not possible, special passing places were designed. As a result, the transportation system was optimally designed, maintaining the minimum area for roads. Besides, some roads were hardened with gravel or covered with asphalt. Research works proved that shortened distances between farm centres and arable parcels may result in reduction of costs between $10 \%$ and $20 \%$.

- The analysis of changes in the water melioration (reclamation) system

Before land consolidation the total area of all water melioration (reclamation) installations equalled to 13.27 ha, including 6.63 ha of basic water melioration facilities and 6.64 ha of detailed water melioration facilities. All installations were generally in poor conditions. Locations of melioration ditches were corrected and their technical parameters (width and depth) were improved. Cadastral records were updated within this field.

\section{The assessment of impacts of land consolidation on the landscape and the environment}

Environmental impact assessment of land consolidation works was performed according to the Act (Ustawa..., 2008) and it proved neutral impacts of land consolidation works on the natural environment in the case study. Protected areas did not occur in the analysed area. Some losses in the landscape were caused by grubbing-up trees and bushes close to water melioration ditches. Insufficient funds did not allow for planting additional trees. Regulation of melioration streams allowed to limit the occurrence of flooded areas. 


\section{The assessment of legal-and-social effects}

As a result of the land consolidation process, the new legal state of designed parcels was legitimised and recorded in the property registers. Cadastral data was also updated for the entire area. From the perspective of social effects, improvements in farming conditions resulted in the increased social satisfaction which affected inhabitants of neighbouring villages and led to their growing interest in land consolidation works.

\section{Conclusions, proposals, recommendations}

Results of land consolidation works are noticeable by farmers mainly in the economic sphere, but environmental-and-landscape or legal-and-social effects may not be neglected. However, in Poland the economic factor related with the reduction of agricultural production costs and the maintenance of the increased incomes is the most important and at the same time it seems to be the most difficult factor for implementation. The research results indicate that activities aiming at the increase of production profitability require efficient co-operation at the level of the public administration, contractors and participants of the land consolidation process.

Economic effects were satisfactory for the analysed area; however, they were not very high. The measurable economic effects include: (i) the reduction of the number of plots by $35 \%$, (ii) the improvement of the geometric proportions of plots, (iii) the reduction of the values of the shape expanse coefficient for the analysed farms by an average of $180 \%$, (iv) the reduction of production costs due to shortening the distance between the plots by an average of $15 \%$, ( $v$ ) reduction of the area of land used as the agricultural roads.

The most effective method which encourages to perform land consolidation works includes the dialogue and social consultations. In this area, land consolidation works performed in the village of Adrianki achieved positive results, since they resulted in the increased interest in land consolidation works among inhabitants of neighbouring villages. But land consolidation did not improve environmental-and-landscape aspects in analysed areas; it remained neutral. Research results indicate that it is required in Poland to constantly promote the idea of multifunctional rural development performed within the process of land consolidation.

\section{Bibliography}

1. Agenda 2000 (The Agenda 2000) (2000). Retrieved:uniaeuropejska.org/agenda-2000/

Access: 02.02.2018.

2. Europejska Karta Obszarow Wiejskich (The European Charter of Rural Areas) (1996). Wies i Rolnictwo, No 2-3, Warszawa.

3. Moszczenski, S. (1927). Nowy sposob ujmowania rozlogu ziemi (The New Approach to Configuration of Lands). Biblioteka Pulawska, Warszawa.

4. Poczta, W. (ed.) (2013). Gospodarstwa rolne w Polsce na tle gospodarstw Unii Europejskiej - wplyw WPR (Farms in Poland versus farms in the European Union - impacts of the CAP). Glowny Urzad Statystyczny, Warszawa.

5. Powszechny Spis Rolny 2010 (The National Agricultural Census) (2010). Glowny Urzad Statystyczny, Warszawa.

6. Roszkowska-Madra, B.(2009). Koncepcje rozwoju europejskiego rolnictwa i obszarow wiejskich (Concepts of development for the European agriculture and rural areas). Gospodarka narodowa. No. 10, p. 83-102.

7. Sobolewska-Mikulska, K. (2009). Kierunki modernizacji struktury przestrzennej obszarow wiejskich po wstapieniu Polski do Unii Europejskiej (Directions of modernisation of the spatial structure of rural areas after the Polish accession to the European Union). Przeglad Geodezyjny. No. 10, p. 11-14. 
8. Spojna polityka strukturalna rozwoju obszarow wiejskich i rolnictwa. Dokument przyjety przez Rade Ministrow w 1999 r. (Coherent structural policy of development of rural areas and agriculture, the document approved by the Council of Ministers in 1999) (1999). Przeglad Rzadowy, No 9, pp. 65-100, Warszawa.

9. Ustawa o scaleniu i wymianie gruntow z dnia 26 marca 1982 r. (The act on land consolidation and exchange of March 26, 1982) (1982). Journal of Law 1982 No 10 pos. 55.

26. Ustawa o udostepnianiu informacji o srodowisku i jego ochronie, udziale spoleczenstwa w ochronie srodowiska oraz o ocenach oddzialywania na srodowisko z dnia 3 października 2008 r. (The act on distribution of information on the environment and its protection, on participation of the society in the natural environment protection and on the environmental impact assessment of October 3, 2008) (2008). Journal of Laws 2008 No 199 pos. 1227.

10. Woch, F. (2006) Perspektywy zmian strukturalnych na obszarach wiejskich, Kompleksowe scalenia gruntow rolnych i lesnych oraz jego wplyw na srodowisko (Perspectives of structural changes in rural areas, Complex consolidation of agricultural and forest lands and its environmental impacts). Materialy szkoleniowe IUNG - PIB Pulawy, No 93, pp. 5-22.

11. Woch, F. (2014). Ocena rozlogu gruntow Polsce oraz potrzeb ich scalania (The assessment of configuration of lands in Poland and demands for land consolidation works). Materialy konferencyjne, IUNG -PIB, Pulawy. 